\title{
Between full LCA and energy certification methodology - a comparison of six methodological variants of buildings environmental assessment
}

\author{
Anna Lewandowska • Andrzej Noskowiak • \\ Grzegorz Pajchrowski • Joanna Zarebska
}

Received: 8 April 2013 / Accepted: 19 September 2014 / Published online: 4 November 2014

(C) The Author(s) 2014. This article is published with open access at Springerlink.com

\begin{abstract}
Purpose Construction, as a sector of the economy, is a significant source of negative environmental impacts. The development of sustainable construction and associated initiatives are meant to reduce that impact. Buildings, for many reasons, are the complex objects of life cycle assessment (LCA) studies, which in this case can be particularly time-, data- and costconsuming. Therefore, an attempt was made to explore the possibility of finding a methodological compromise between a full LCA and the compulsory energy certification. Six methodological variants, so called compromise solutions (CS) were identified and assessed. This article presents the results of the research project financed by the Polish Ministry of Science and Higher Education (N N309 078138) and coordinated by the Wood Technology Institute in Poznan.

Methods The proposed CS were hybrids utilising, to various degrees, the environmental life cycle assessment (LCA) and energy certification. Life cycle impact assessments were carried out using IMPACT 2002+.

Results and discussion The achieved results showed that the simplifications included in the energy certification lead to a significant drop in environmental impacts (by $77.9 \%$ on average) in relation to the impact calculated for the full
\end{abstract}

Responsible editor: Alexander Passer

A. Lewandowska $(\bowtie)$

Faculty of Commodity Science, Poznan University of Economics,

Niepodleglosci av. 10, Poznan 61-875, Poland

e-mail: anna.lewandowska@ue.poznan.pl

A. Noskowiak $\cdot$ G. Pajchrowski

Wood Technology Institute, Winiarska Str 1, 60-654 Poznan, Poland

J. Zarebska

Faculty of Economics and Management, University of Zielona Gora, Podgorna 50, 65-246 Zielona Gora, Poland
LCA. The results closest to the full LCA were achieved by the compromise solution no. 4 (CS4), where simplification included the exclusion from the life cycle of: transport processes, construction site, demolition, final disposal of waste, and the majority of elements associated with the use of the building. CS4 analysed all inventory inputs which were assessed with regard to the entire environmental profile. The following truncation levels were achieved for CS4-10.7\% (conventional masonry building), $9.9 \%$ (passive masonry building), $8.3 \%$ (conventional wooden building) and $7.4 \%$ (passive wooden building), indicating that $90 \%$ of the impact calculated for the full LCA was retained.

Conclusions CS4 seems to be a rational compromise between the simplicity of the methodology and the environmental significance. With the exception of the energy usage for heating, hot water and ventilation, CS4 also proposes including, in the analysis, the production of building material and additional elements associated with the use stage, e.g. energy usage for home appliances and lighting, land occupation, water use and wastewater treatment. However, if we were to find a rational minimum, which is close to the energy certification, then a good improvement of this methodology would be to include energy usage for home appliances and lighting as well as introducing conversion indicators, based not only on the depletion of energy resources, but also factoring in global warming and respiratory effects/inorganic compounds. Moreover, it seems that the LCA methodology and, specifically, characterisation factors, are refined to such a degree and scientifically proved that it would be possible to use the knowledge with regard to LCA to establish such indicators for energy certification.

Keywords Buildings $\cdot$ Energy certification $\cdot$ Environmental impact $\cdot$ Life cycle $\cdot$ Simplifications 


\section{Life cycle assessment and energy certification-similarities and differences}

The energy certification of buildings across the European Union is in accordance with the Directive 2010/31/EU of the European Parliament (Directive 2010/31/EU) and of the Council of 19 May 2010 on the energy performance of buildings and which repeals 2002/91/WE of 16 December 2002 (Directive 2002/91/ EU). The directive includes the guidelines with regard to the minimal requirements and general regulations. Energy performance certificates are evidence of the buildings' energy demand throughout their use. They provide data regarding energy performance obtained from the calculations according to the assessment methodology chosen for a given country or region, and provide recommendations aimed at improving the given performance with regard to its cost-effectiveness. Certificates may also include data pertaining to $\mathrm{CO} 2$ emissions indicators (not practiced in Poland). Full energy demand covers the energy used for heating (including heat loss due to permeability and ventilation), hot water and additional electric energy used as auxiliary energy. This is in accordance with the Minister of Infrastructure's 6 November 2008 regulation on the methodology of calculating the energy performance of buildings and residential dwellings (or part of a building that comprises a self-contained entity) and the preparation and presentation of energy performance certificates (OJ No 201, item 2008. 1,240) for dwellings without cooling systems. With regard to residential dwellings, electric energy used for lighting or home appliances is not taken into consideration. In line with the methodology adopted in Poland, the key parameter reflecting the energy performance of a building is the non-renewable primary energy demand indicator.

It is represented in energy certification by the reference indicator dependent on the building shape factor (O.J. 2002 No 75, item. 690 as amended 2002), which is calculated as the ratio of the surface of all partitions separating the heated part of the building from outside air, land and non-heated rooms to the volume of the heated part of the building. Energy certification also includes the final energy demand indicator, which represents the energy balanced out at a building's exterior boundaries (O.J. No 201, item 2008. 1,240). The majority of publications with regard to environmental consequences of buildings emphasise the prevailing share of energy-related impacts in the entire structure of environmental issues. Therefore, there is no doubt that it is the use of energy (primary, secondary) in different stages of the life cycle of buildings that is one of the main issues which requires attention, since it is linked to both the extraction and the use of non-renewable sources as well as greenhouse gas emissions or acidifying compounds (Kulczycka and Pietrzyk-Sokulska 2012). A common denominator for LCA and the introduction of the energy performance certification regulation can be recognised as the reduction of negative impact on environment through the increase of the energy efficiency (quality) of buildings. Both can be described as eco-design (understood as an approach to design buildings with the best energy performance) stimulating tools. This is however the only common feature of LCA and energy certification, since there are significant differences between both methodologies (Table 1):

In Poland, energy performance certificates according to the amendment to the Building Act of 19 September 2007, and the amendment of 27 August 2009 (The Act of 7 July 1994), are obligatory and all new buildings and the buildings or premises sold or rented are subject to certification. LCA is, however, as an element of ISO 14000 series, voluntary. Energy certification is, in terms of methodology, a much simpler tool (OJ No 201, item 2008. 1,240) and includes only selected elements, which are also present in the environmental life cycle assessment. Using the LCA terminology, it can be stated that they only include energy-related environmental aspects

Table 1 LCA and energy certificates-differences

\begin{tabular}{|c|c|c|}
\hline Feature & LCA & Energy certification (in Poland) \\
\hline Mode of functioning & Voluntary & Obligatory \\
\hline Life cycle perspective & The entire life cycle & Only selected elements of use (heating, ventilation, hot water) \\
\hline Environmental aspects & $\begin{array}{l}\text { A wide spectrum of aspects, for example: land } \\
\text { occupation and transformation, minerals } \\
\text { consumption, primary and secondary energy } \\
\text { usage, water consumption, transport, emissions to } \\
\text { air, water and soil, ionizing radiation, use of } \\
\text { processed materials (plastics, metals, ceramic, etc.) }\end{array}$ & Primary and secondary energy consumption \\
\hline Environmental consequences & $\begin{array}{l}\text { A wide spectrum of consequences, for example: } \\
\text { respiratory effects, global warming, acidification, } \\
\text { eutrophication, human toxicity, ecotoxicity, ozone } \\
\text { layer depletion }\end{array}$ & Energy resources depletion \\
\hline Methodology & Normalized (ISO 14040 2006; ISO 14044 2006) & Normalized (O.J. 2008 No 201, item. 1,240) \\
\hline Impact modelling & Yes (midpoint or endpoint approach) & No, inventory level \\
\hline
\end{tabular}

Source: Lewandowska et al. (2012) 
occurring in the use stage: use of primary energy from carriers such as natural gas, coal, lignite, biomass, thermal solar collectors, as well as bio-gas and the use of secondary energy as heating oil, liquid gas, heat from coal, gas-oil and bio-mass heating plants (OJ No 201, item 2008. 1,240). Additionally, the regulation (OJ No 201, item 2008. 1,240) with regard to the energy certification methodology states that "alongside the use of energy, the related emissions of $\mathrm{CO} 2$ associated with building can be included." This means that the second of the aspects assessed through certification can be emissions of $\mathrm{CO} 2$; however, in Poland, this is not practiced. The abovementioned energy use (and possible emissions of $\mathrm{CO} 2$ ) is not analysed in relation to the full life cycle but only for selected areas of the building use such as heating, ventilation as well as hot water. LCA gathers data with regard to a wide spectrum of environmental aspects, not limited to energy or $\mathrm{CO} 2$ emissions but also including the use of other renewable, as well as non-renewable, resources including: the use of raw materials or pre-made materials from technosphere; land occupation and transformation; emissions of many organic and non-organic compounds into the air, water and soil, as well as emissions of ionizing radiation. LCA, in contrast to energy certification, analyses all of the above-mentioned aspects with regard to the entire life cycle of the building.

The next element differentiating both tools is the recognition of environmental impact. The LCA methodology assumes, within phase three (LCIA), the assessment of the environmental impact based on certain characterisation models and impact indicators. As a result, it is possible to qualify and quantify the impact (or damage) on the environment leading to strictly defined environmental issues (impact or damage category) such as: carcinogenicity, respiratory disorders, climate changes (global warming), ozone layer depletion, ecotoxicity and various others. In the case of energy certification, it is difficult to talk about assessing the environmental impact because the process does not really include indicators recognising levels of impact modelling resembling those of LCI. At the most, it can be stated that energy performance certificates use indicators from the LCI level, tracking the amount of used energy (input indicators are equivalents of embodied energy indicators or of the cumulative demand for energy as well as the $\mathrm{CO} 2$ emission). It is worth observing that the optionally included $\mathrm{CO} 2$ emissions in energy certification do not relate to $\mathrm{CO} 2$ equivalents (as the common unit of impact category global warming or climate changes, which includes and tracks the entire emission of all greenhouse gases) but only relates to $\mathrm{CO} 2$ itself. Assuming this is a substitute of the assessment of environmental impact, it can be established that energy certification, in its widest scope, covers two environmental issues: global warming (climate changes) and depletion of (energy) sources.

\section{LCA of buildings-simplifications}

The key question in the context of simplified energy certification and the complex LCA procedures is whether it is possible to establish a methodological compromise solution. The commonly formulated reservation with regard to LCA is that it is too time-consuming and too complex. On the other hand, energy certification is noted as far too simplified (Casals 2006). It's argued that, most often, improvements leading to a reduction of energy use in the certified areas, i.e. heating, ventilation and hot water lead to an increased use of building materials (mainly aluminium, steel, glass, insulation materials) as well as additional HVAC demand (heating, ventilation, air conditioning). This leads to an increased use of materials and energy in other stages of the life cycle, not included in energy certification. Only comparing all the changes with regard to material and energy intensity, as well as emissions for the full life cycle, would establish whether the given innovation is environmentally backed.

One of the questions in this process is with regard to which of the life cycle stages are to be included and which excluded. The following life cycle stages of a building are suggested in EN 158042012 established by CEN/TC 350 (EN 15804 2012): product stage (raw material supply, transport, manufacturing), construction process stage (transport to the building site, building installation), use stage (repair and replacement, refurbishment, energy use, water use) and end of life (deconstruction, transport, recycling/resume, disposal). A similar approach is suggested by International Organization for Standardization in standard of ISO 21931 (ISO 21931-1 2010) (Table 2). The simplifications in life cycle assessment of buildings were the focus of interest for many authors. Blengini and Carlo (Blengini and Carlo 2010) include 19 examples of LCA regarding life cycle stages of buildings. The following are identified: construction materials (production), equipment/interior materials (production), transport, construction, maintenance, use, final disposal (Blengini and Carlo 2010a, b). All analysed cases of LCA included production stages of materials included in the building construction as well as its usage. Eighteen cases included transport and maintenance; 14 included construction stages; $63.16 \%$ cases included final disposal; equipment materials production stage was included in (the least) eight examples. Another publication with regard to the link between energy certification and LCA (Bribian et al. 2009) proposes a simplification of LCA and exclusion of the following stages from the life cycle: transport of materials to construction site, erecting of the building, maintenance, repairs and refurbishments, renovation, water usage, demolition/dismantling, transport of waste and final disposal of waste (Table 2). The ENSLIC Building Project is another example of initiative taken with the aim of LCA's simplification, and stimulating collaboration between LCA experts and building practitioners (Malmqvist et al. 
Table 2 Life cycle stages of building included in LCA studies

\begin{tabular}{|c|c|c|c|c|c|c|}
\hline Life cycle stages & Modules & $\begin{array}{l}\text { CEN/TC } 350 \\
\text { (EN } 158042012)\end{array}$ & $\begin{array}{l}\text { ISO TC/59 } \\
\text { (ISO 21931-1 2010) }\end{array}$ & $\begin{array}{l}\text { Bribian } \\
\text { et al. } 2009\end{array}$ & $\begin{array}{l}\text { Kellenberger and } \\
\text { Althaus } 2009\end{array}$ & $\begin{array}{l}\text { Malmqvist } \\
\text { et al. } 2011\end{array}$ \\
\hline \multirow[t]{3}{*}{ I. Product stage } & Raw material supply & Included & Included & Included & Included & Included \\
\hline & Transport & Included & Included & Included & No data & No data \\
\hline & Manufacturing & Included & Included & Included & Included & Included \\
\hline \multirow{2}{*}{$\begin{array}{l}\text { II. Construction } \\
\text { process stage }\end{array}$} & Transport & Included & Included & Excluded & Included & Included \\
\hline & Building erection & Included & Included & Excluded & Included & Included \\
\hline \multirow[t]{6}{*}{ III. Use stage } & Maintaining order and cleanliness & Included & Included & Excluded & Excluded & Included \\
\hline & Repairs and replacements & Included & Included & Excluded & Included & Included \\
\hline & $\begin{array}{l}\text { Refurbishment (renovations and } \\
\text { conservations) }\end{array}$ & Included & Included & Excluded & Excluded & Excluded \\
\hline & $\begin{array}{l}\text { Energy consumption for heating, } \\
\text { cooling, ventilation, hot water } \\
\text { preparation and lighting }\end{array}$ & Included & Included & Included & Included & Included \\
\hline & Water consumption & Included & Included & Excluded & Excluded & Included \\
\hline & Waste treatment/disposal & Excluded & Included & Excluded & Excluded & Excluded \\
\hline \multirow[t]{4}{*}{ IV. End of life stage } & Demolition & Included & Included & Excluded & Excluded & Excluded \\
\hline & Transport & Included & Included & Excluded & Excluded & Excluded \\
\hline & Recycling/reuse & Included & Included & Excluded & Included & Included \\
\hline & Final disposal of waste & Included & Included & Excluded & Included & Included \\
\hline
\end{tabular}

2011). The simplified and publicly available LCA tool was developed as one of the outcomes of the ENSLIC project (ENSLIC). The relevance of simplifications in LCA of building components are also discussed by Kellenberger and Althaus (Kellenberger and Althaus 2009). The authors made the comparative analyses between five building components by using the cumulative non-renewable energy and ecoindicator 99 (H/A) approaches. They performed the studies with five levels of detailing ("from all inclusive to fully reduced"). The LCA results between the extremes differed between 15 and $30 \%$ (Kellenberger and Althaus 2009). Other important works related to the residential buildings and the role of particular life cycle stages in the environmental assessment of buildings with special focus on energyrelated aspects are those of Dixit et al. (2010), Ortiz et al. (2009), Optis and Wild ( 2010), Dylewski and Adamczyk ( 2012), Passer et al. (2012) and Rossi et al. (2012).

Based on the above considerations, it is possible to state the following:

- Environmental life cycle assessment and energy certification represent related tools both contributing to proenvironment building improvement.

- The range of data obtained from the use of both tools differs significantly. Energy certification considers proenvironment improvement with regard to the energy used with regard to the building usage, whilst LCA takes into consideration many more aspects and environmental consequences regarding the full life cycle.
- Energy performance certificates as compulsory tools are known to various stakeholders included in the life cycle of buildings whilst LCA is still a novelty.

- The full LCA can be perceived as too complex and too difficult to apply in practice, especially with regard to such complex objects of analysis as buildings.

- Energy certification can be perceived as too simplified, especially in relation to the possibilities and a wide scope of results obtained with LCA.

- There are publications that evidence trials to combine both methodologies, for example, Bribian et al. (2009).

\section{Residential buildings under study—description}

Analysed were four model detached residential buildings intended for a four-person family and with the usable space of $98.04 \mathrm{~m}^{2}$. The buildings differed with regard to the material structure, technology and energy performance. Analysed were: a masonry conventional building (A1), a masonry passive building (A2), a wooden conventional building (B1) as well as a wooden passive building (B2) (Fig. 1). All were onestorey buildings with the following plan: entry hall, toilet, day/ living room with dining area, kitchen, double bedroom, two single rooms, bathroom as well as utility room. The functional unit was defined as: "provision of $98.04 \mathrm{~ms}$ of the usable space of the buildings fit for use over 100 years and protection during that period of the users and objects from harmful external factors." 
Fig. 1 Buildings selected for analysis. Source: Lewandowska et al. (2012)

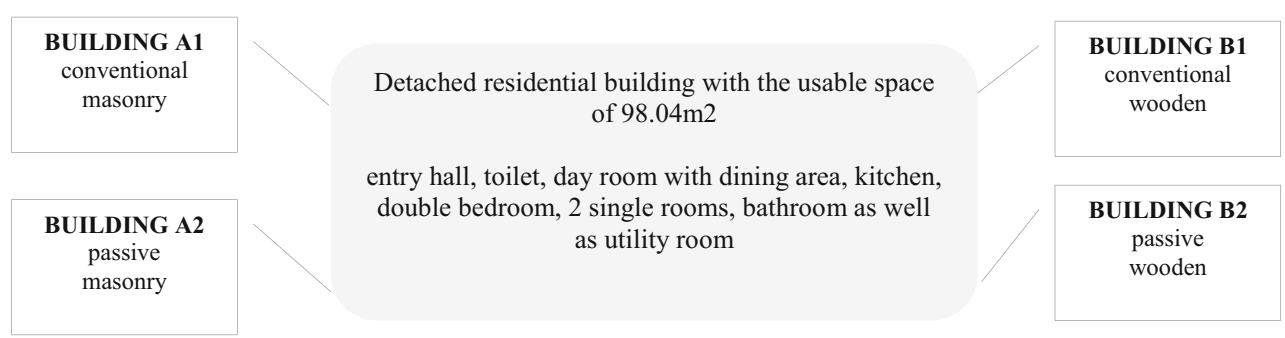

For each of the above-mentioned buildings, a separate architectural project was prepared by the architect's office.

Materials usage, usage parameters, installation as well as usage of energy carriers was calculated individually for each of the buildings whilst versions A2 and B2 included the requirements with regard to passive buildings. Buildings are assumed to be positioned in a certain relation to the cardinal directions to maximise the use of sun rays (large windows on the south wall). This is particularly important in case of passive buildings.

The construction system and the method of foundation of the analysed buildings are assumed as follows (Lewandowska et al. 2012):

- Masonry conventional building (A1): load-bearing structure in a longitudinal arrangement, with load-bearing walls built using single-layer SOLBET masonry, beam and block ceiling, traditional wood roof with a collar beam, building foundation laid on a continuous footing, continuous footing made of concrete (thickness $30 \mathrm{~cm}$ ), laid directly on the bearing soil;

- Masonry passive building (A2): load-bearing structure in a longitudinal arrangement, with load-bearing walls built using double-layer masonry, beam and block ceiling, traditional wood roof with a collar beam, building placed on the concrete foundation slab (thickness $25 \mathrm{~cm}$ ) laid on the bearing soil via thermal insulation boards (XPS);

- A wooden conventional building (B1): load-bearing structure in a longitudinal arrangement, with load-bearing walls built using a light framework, ceiling and pitched roof constructed using lattice trusses, building placed on the concrete continuous footing (thickness $30 \mathrm{~cm}$ ) founded directly on the bearing soil;

- A wooden passive building (B2): load-bearing wall structure in a longitudinal arrangement, with load-bearing walls built using a light framework, ceiling and pitched roof constructed using lattice trusses, building placed on the concrete foundation slab (thickness $20 \mathrm{~cm}$ ) laid on the bearing soil via thermal insulation granules (foam glass granulate).

In case of wooden buildings (B1 and B2), the maximum usage of wood and wood-related materials was assumed. The wooden elements can be found in the roof (wood shake, coniferous timber), ceiling structure (OSB, fire-resistant plasterboard), ceiling insulation (wood wool/B1/or cellulose/B2/), external wall structure (OSB, fire-resistant plasterboard), external wall insulation (wood wool/B1/or cellulose /B2/), internal wall structure and gables' construction (OSB, fire-resistant plasterboard), internal window sills and window frames (softwood) and floor (hardwood floorboard). In cases of buildings $\mathrm{A} 1$ and $\mathrm{A} 2$, the use of wooden materials was limited to minimum (Table 3).

The masonry buildings are considerably weightier. The total mass of building materials used to construct houses A1 and A2 was 217986.7 and $244282.34 \mathrm{~kg}$, respectively (Table 4). More than $90 \%$ of total mass of masonry buildings consists of concrete, natural stone materials and ceramics. The wooden houses are slighter (B1=150 993.8 and B2=91 $623.8 \mathrm{~kg}$ ), and the share of wood and wood-based materials is total mass more evident (Table 4).

The annual consumption of electricity, heat and water during the operation of the analysed buildings is presented in Table 5. More information about system boundaries and inventory data assumed in the presented comparative study for four residential buildings can be found in Pajchrowski et al. (2014a, b).

\section{Six variants of LCA detailing ("compromise solutions")}

Energy certification in comparison with LCA is a simplification with regard to three areas: scope (life cycle), environmental aspects (LCI) as well as environmental consequences (LCIA) (Fig. 2). Therefore, a modification in those three areas has been proposed.

Taking into account the above evidence, it has been agreed to establish and analyse a compromise solution, which would combine the methodological aspects of both LCA and energy certification. Clearly formulating a single solution would appear difficult, and such a task would require establishing of a number of hybrid approaches. Table 3 illustrates the proposed six compromise solutions (CS) representing various combinations of selected methodological elements of LCA and energy certification:

- CS1 is a reflection of the full LCA, according to which all stages of the entire life cycle of buildings are included; all 
Table 3 The use of wood and wood-based materials in the analysed houses

\begin{tabular}{|c|c|c|c|c|}
\hline \multirow[t]{2}{*}{ Building module } & \multicolumn{2}{|l|}{ Masonry houses } & \multicolumn{2}{|l|}{ Wooden houses } \\
\hline & A1 conventional & A2 passive & B1 conventional & B2 passive \\
\hline Roofing, roof & Concrete roof tiles & Concrete roof tiles & Wood shake & Wood shake \\
\hline Roof structure & Coniferous timber & Coniferous timber & Coniferous timber & Coniferous timber \\
\hline Ceiling structure & Cellular concrete blocks & Calcium silicate blocks & OSB, fire-resistant plasterboard & OSB, fire-resistant plasterboard \\
\hline Ceiling insulation & EPS & EPS & Wood wool & Cellulose \\
\hline External wall structure & Cellular concrete blocks & Calcium silicate blocks & OSB, fire-resistant plasterboard & OSB, fire-resistant plasterboard \\
\hline External wall insulation & EPS & EPS & Wood wool & Cellulose \\
\hline Internal wall structure & Cellular concrete blocks & Calcium silicate blocks & OSB, fire-resistant plasterboard & OSB, fire-resistant plasterboard \\
\hline Gables' construction & Cellular concrete blocks & Calcium silicate blocks & OSB, fire-resistant plasterboard & OSB, fire-resistant plasterboard \\
\hline Internal window sills & PVC & PVC & Softwood & Softwood \\
\hline Floor finish & Ceramic tile & Ceramic tile & Hardwood floorboard & Hardwood floorboard \\
\hline Window frames & PVC & $\mathrm{PVC}$ & Wood & Wood \\
\hline Façade & External plaster, façade paint & External plaster, façade paint & Softwood façade board & Softwood façade board \\
\hline
\end{tabular}

Source: Pajchrowski et al. (2014a)

environmental aspects characteristic to individual stages as well as the entire spectrum of environmental issues included in the environmental profile associated with a chosen LCIA method (Impact 2002+) is taken into account. Assumingly, this model should provide a wide range of information about inventory data as well as the type and size of the impact on environment. The potential weaknesses of this method are time consumption of as well as high requirements with regard to the data.

- CS2 covers the entire life cycle characteristic for the full LCA; however, the collated inventory data for each of the analysed stages are analysed in line with energy certification, only with regard to the usage of energy carriers. This approach differs from energy certification, since the analysis covers the typical for energy certification environmental consequences, but the analysis is not limited to use stage only but covers all stages of life cycle.

- CS3: In this case the scope of the analysis includes selected elements of the stage of use typical for energy certification (energy use for: heating, ventilation, hot water), but the inventory analysis is not limited to the depletion of energy carriers and also includes all other input- and output-related environmental aspects typical for LCA (material use and emissions). The impact assessment covers the whole environmental profile.

- CS4, model 4, suggests a simplification of life cycle according to the majority of guidelines included in the publication (Bribian et al. 2009) with additionally included non-energy aspects such as: land occupation, use of water and wastewater treatment. These aspects with full
Table 4 Use of different building materials in the analysed buildings (as percent share in total mass of materials)
Source: Pajchrowski et al. (2014b)

\begin{tabular}{|c|c|c|c|c|c|}
\hline \multirow[t]{2}{*}{ Type of building materials } & \multicolumn{2}{|l|}{ Masonry houses } & \multicolumn{2}{|l|}{ Wooden houses } & \multirow[t]{2}{*}{ Unit } \\
\hline & A1 conventional & A2 passive & B1 conventional & B2 passive & \\
\hline Concrete & 49.1 & 41.4 & 39.8 & 58.8 & $\%$ \\
\hline Natural stone materials & 34.0 & 42.7 & 45.5 & 0.0 & $\%$ \\
\hline Building ceramics & 7.5 & 6.7 & 0.5 & 0.9 & $\%$ \\
\hline $\begin{array}{l}\text { Mineral binding materials, as } \\
\text { well as grouts and mortars }\end{array}$ & 4.9 & 3.4 & 0.9 & 0.8 & $\%$ \\
\hline Wood/wood-based materials & 1.9 & 1.7 & 9.0 & 20.4 & $\%$ \\
\hline Metals & 1.8 & 2.1 & 0.8 & 1.6 & $\%$ \\
\hline Plastics & 0.6 & 1.6 & 0.7 & 0.7 & $\%$ \\
\hline Glass & 0.1 & 0.3 & 0.2 & 12.8 & $\%$ \\
\hline Preservatives and paints & 0.1 & 0.1 & 0.1 & 0.2 & $\%$ \\
\hline Plasterboards & 0.0 & 0.0 & 2.4 & 4.0 & $\%$ \\
\hline Sum & 100.0 & 100.0 & 100.0 & 100.0 & $\%$ \\
\hline Total mass & $217,986.7$ & $244,282.34$ & $150,993.8$ & $91,623.8$ & $\mathrm{~kg}$ \\
\hline
\end{tabular}


Table 5 The annual consumption of electricity, heat and water during the operation of the buildings

\begin{tabular}{|c|c|c|c|c|c|}
\hline Houses & A1 traditional masonry & A2 Passive masonry & B1 traditional wooden & B2 passive wooden & Unit \\
\hline Electricity: rtv and household equipment & $1,600.0$ & $1,600.0$ & $1,600.0$ & $1,600.0$ & $\mathrm{kWh} /$ year \\
\hline Electricity: lighting & 350.0 & 350.0 & 350.0 & 350.0 & $\mathrm{kWh} /$ year \\
\hline Electricity: heating & - & $1,429.5$ & - & $1,470.4$ & $\mathrm{kWh} /$ year \\
\hline Electricity: hot tap water & - & $3,010.9$ & - & $3,010.9$ & $\mathrm{kWh} / \mathrm{year}$ \\
\hline Electricity, ventilation & - & 343.5 & - & 343.5 & $\mathrm{kWh} / \mathrm{year}$ \\
\hline Heat (natural gas), heating & $15,637.7$ & - & $15,484.7$ & - & $\mathrm{kWh} /$ year \\
\hline Heat (natural gas), hot tap water & $6,584.5$ & - & $6,584.5$ & - & $\mathrm{kWh} /$ year \\
\hline Electricity (ancillary) & 130.8 & - & 130.8 & - & $\mathrm{kWh} / \mathrm{year}$ \\
\hline Hot water $\left(55^{\circ} \mathrm{C}\right)$ & $45,990.0$ & $45,990.0$ & $45,990.0$ & $45,990.0$ & Litres/year \\
\hline Cold water & $85,410.0$ & $85,410.0$ & $85,410.0$ & $85,410.0$ & Litres/year \\
\hline Sewage & $131,400.0$ & $131,400.0$ & $131,400.0$ & $131,400.0$ & Litres/year \\
\hline
\end{tabular}

Source: Pajchrowski et al. (2014b)

LCI data assigned to them will be analysed with regard to all impact categories included in Impact 2002+ method.

- CS5: It is proposed that this model uses the same scope of life cycle as model 4; however, the analysis is to be carried out from the point of view typical for energy certification, i.e. use of energy carriers.

- CS6: The last model assumes analysis according to the energy certification and may be perceived as the simplest solution. This method analyses only selected elements of usage (use of energy for: heating, ventilation, hot water) and from the point of view of use of energy sources (LCIA).

More detailed description of all compromise solutions has been shown in Table 6. In the full LCA (CS1), the entire life cycle of analysed buildings has been assessed whilst, in the remaining cases, the analysis covered only selected elements. The most simplified version is variant SC6. A more detailed overview of each of the compromise solutions has been included in Table 7.

\section{LCA calculations for six compromise solutions (CS)}

For each of the buildings and compromise solutions, inventory data within the scope, shown in Table 7, was entered to SimaPro Analyst v.7.3.0 (Ecoinvent v. 2.2). In full LCA (CS1), combined for all stages of the life cycle (at level "zero" of product system, without suppliers), 474 inventory points were gathered for building A1 (masonry conventional), 453 for A2 (masonry passive), 584 for B1 (wooden conventional) and 552 for B2 (wooden passive). The completeness of the data was verified by mass balance. LCIA was carried out with IMPACT 2002+ method.

Below, Table 8 shows the eco indicator results for six proposed CS with regard to the four analysed buildings (A1, A2, B1, B2). Figures 3, 4, 5 and 6 show the same results in terms of percentage values. The difference in the height of the graphs equals the difference of ecoindicator values between full LCA/CS1 $(100 \%)$ and every other compromise solution. The results show the highest truncation level for CS6 identified with energy
Fig. 2 Areas of potential modification of LCA and energy certification. Source: Lewandowska et al. (2012)

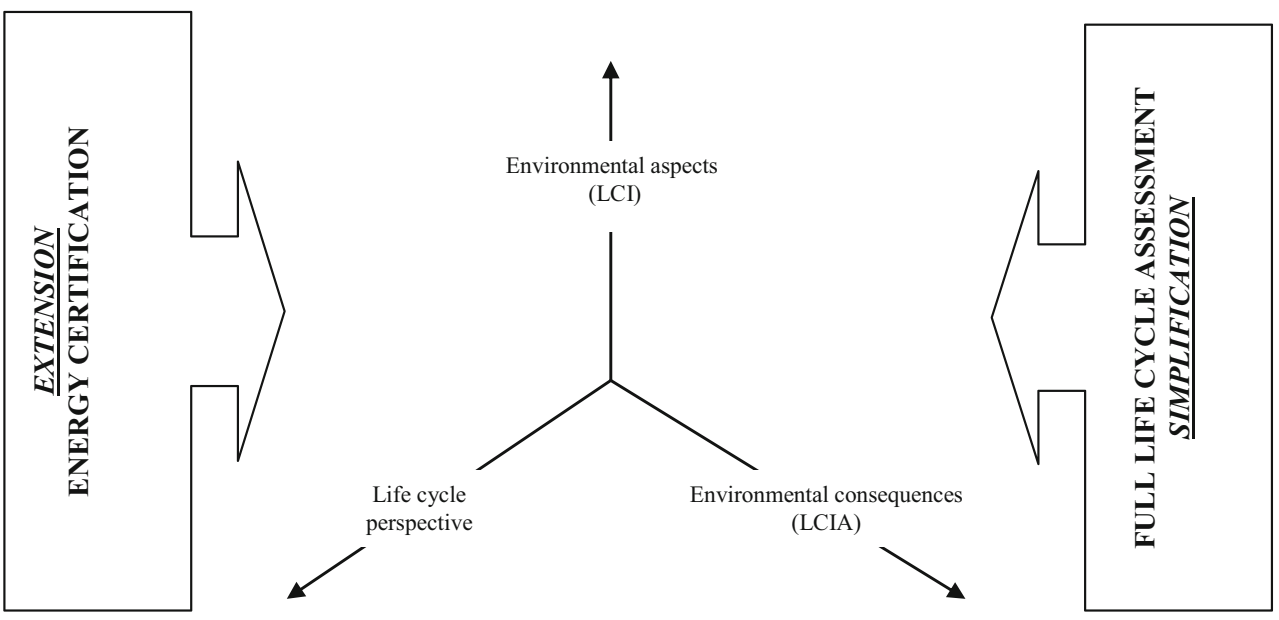




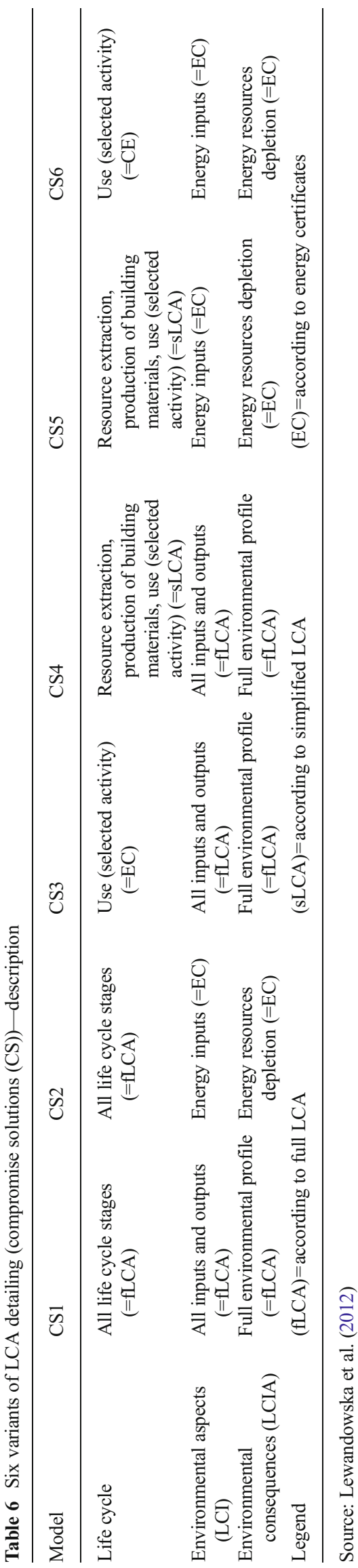

certification. However, if including only the use of energy carriers with regard to selected use elements, then the results indicator in comparison to $\mathrm{SC} 1$ is lower by $72.8 \%$ for A1 (masonry conventional), $84.4 \%$ for A2 (masonry passive), $70.9 \%$ for B1 (wooden conventional) and $83.4 \%$ for B2 (wooden passive). Based on the carried out analyses, the solution closest to CS1 is CS4, which generates results close to LCIA (truncation level of $10.7 \%$ (A1), $9.9 \%$ (A2), $8.3 \%$ (B1) and $7.4 \%$ for B2), thus making it possible to be accepted as a compromise, since it does not affect the final relations with regard to obtained results for the full LCA. Moreover, the truncation level was obtained regardless of the type of the building (Table 8, Figs. 3, 4, 5 and 6).

LCA carried out only for two stages: production of building materials and selected elements of use stage retains more than $90 \%$ of impact on environment regardless of the type of the building. Exclusion of transport, construction site, demolition as well as final disposal of waste do not significantly affect the final results.

In the cases of SC1, SC3 and SC4, where all impact categories included in Impact2002+ were analysed, the qualitative structure of impact remained generally unchanged, and three issues were dominant: respiratory effects/inorganic compounds, global warming and renewable energy. This is due to the domination of the impact by energy aspects, which are characterised by creation of environmental impact within the scope of the aforementioned impact categories. Figure 7 below shows, as an example, the weighted impact categories indicator results for building A1 (masonry conventional); however, a similar environmental impact structure was found for all four buildings, regardless of their material structure or energy performance. As shown, solutions CS2, CS5 and CS6, for which inventory includes only energy inputs, show impact within one impact category, non-renewable energy. Since the life cycle scope for which data about the use of energy was collected was different (widest for CS2), the height of the graphs for these three solutions is varied (with the highest for CS2).

In the case of three compromise solutions, CS1, CS3 and CS4, selected inventory elements were analysed with regard to all environmental issues represented by impact categories included in Impact2002+. The average truncation level of LCIA results for the aforementioned three CS varied between $0.0 \%$ for CS1 (full LCA) to $9.1 \%$ for CS4 and $42.9 \%$ for CS3 (Table 8). The main question remains: What level of reduction of LCI data was behind each of the solutions? In case of the full LCA (CS1), gathered in the inventory tables with regard to the entire life cycle were 2,063 of inventory points 
Table 7 System boundaries in six variant of LCA detailing ("Compromise solutions")

\begin{tabular}{|c|c|c|c|}
\hline Compromise solution & System boundaries & LCI results included & LCIA results included \\
\hline CS1 & $\begin{array}{l}\text { 1. Production of building materials } \\
\text { 2. Transport to building site } \\
\text { 3. Construction } \\
\text { - A construction of building components and a whole } \\
\text { building erection } \\
\text { - Transport of building equipment } \\
\text { - Transport of building crew } \\
\text { - A temporary heating } \\
\text { - A water usage for living of building crew } \\
\text { - An electricity usage by building equipment } \\
\text { - A work of digger and loader } \\
\text { - A transport and a final disposal of waste } \\
\text { generated on a building site } \\
\text { 4. Use } \\
\text { - Replacements, renovations and repairs } \\
\text { - Heating } \\
\text { - Ventilation } \\
\text { - Electrical equipment operation } \\
\text { - Cooling } \\
\text { - Hot water preparation } \\
\text { - Lighting } \\
\text { - land occupation } \\
\text { - water consumption and sewage treatment } \\
\text { - final disposal of waste generated during a use period } \\
\text { 5. DEMOLITION } \\
\text { 6. TRANSPORT OF WASTE AFTER DEMOLITION } \\
\text { 7. FINAL DISPOSAL OF WASTE AFTER DEMOLITION }\end{array}$ & All inputs and outputs & Full environmental profile \\
\hline $\mathrm{CS} 2$ & $\begin{array}{l}\text { 1. Production of building materials } \\
\text { 2. Transport to building site } \\
\text { 3. Construction } \\
\text { - A construction of building components and a } \\
\text { whole building erection } \\
\text { - Transport of building equipment } \\
\text { - Transport of building crew } \\
\text { - A temporary heating } \\
\text { - A water usage for living of building crew } \\
\text { - An electricity usage by building equipment } \\
\text { - A work of digger and loader } \\
\text { - A transport and a final disposal of waste generated } \\
\text { on a building site } \\
\text { 4. Use } \\
\text { - Replacements, renovations and repairs } \\
\text { - Heating } \\
\text { - Ventilation } \\
\text { - Electrical equipment operation } \\
\text { - Cooling } \\
\text { - Hot water preparation } \\
\text { - Lighting } \\
\text { - land occupation } \\
\text { - water consumption and sewage treatment } \\
\text { - final disposal of waste generated during a use period } \\
\text { 5. DEMOLITION } \\
\text { 6. TRANSPORT OF WASTE AFTER DEMOLITION } \\
\text { 7. FINAL DISPOSAL OF WASTE AFTER DEMOLITION }\end{array}$ & Energy inputs & Energy resources depletion \\
\hline $\mathrm{CS} 3$ & $\begin{array}{l}\text { 1. Use } \\
\text { - Heating } \\
\text { - Ventilation } \\
\text { - Cooling } \\
\text { - Hot water preparation }\end{array}$ & All inputs and outputs & Full environmental profile \\
\hline CS4 & 1. Production of building materials & All inputs and outputs & Full environmental profile \\
\hline
\end{tabular}

- Heating 
Table 7 (continued)

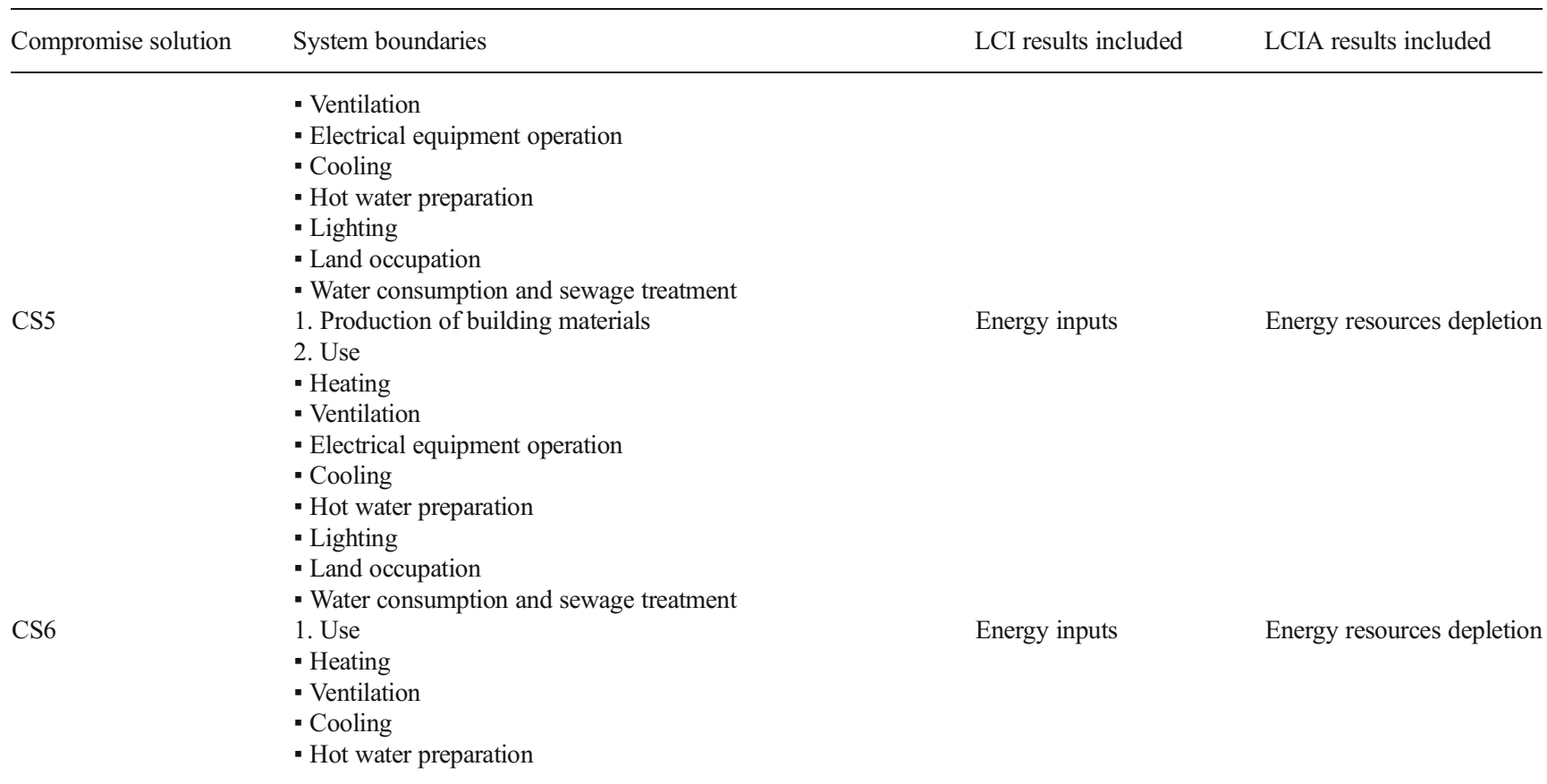

Source: Lewandowska et al. (2012)

(474 building A1, 453 building A2, 584 building B1 and 552 building B2) which related to the "zero" level of product system (no suppliers) with regard to seven separated life cycle stages (according to Table 7). The following eco-indicator results were obtained for this amount of data-249.1 Pt (A1), 270.6 Pt (A2), 230.7 $\mathrm{Pt}$ (B1) and 257.1 Pt (B2) (Tables 8 and 9). In the case of CS3, only three selected elements of use were included (according to energy certification): use of energy for heating, ventilation and hot water. As shown in Table 8, LCI data were reduced by $99.4 \%$ (A1), $99.3 \%$ (A2), $99.5 \%$ (B1) and $99.5 \%$ (B2). However, it would appear that this were vital data, since $0.6 \%$ of all LCI data generated impact equal to $60 \%$ of the ecoindicator result. In the case of $\mathrm{CS} 4$, the production of building materials and extended list of usage elements (land occupation, energy use for heating, ventilation, lighting, home appliances, hot water, water use and
Table 8 Eco-indicator results [Pt] and truncation levels [\%] for six compromise solutions (CS) (source: SimaPro Analyst v.7.3.0/ Impact 2002+)

\begin{tabular}{lllllll}
\hline Building A1 (masonry conventional) & & & & & & \\
Compromise solution (CS) & CS1 & CS2 & CS3 & CS4 & CS5 & CS6 \\
Environmental impact [Pt] & 249.1 & 91.8 & 134.6 & 222.6 & 85.1 & 67.6 \\
Truncation level [\%] & 0.0 & 63.2 & 46.0 & 10.7 & 65.9 & 72.8 \\
Building A2 (masonry passive) & & & & & & \\
Compromise solution (CS) & CS1 & CS2 & CS3 & CS4 & CS5 & CS6 \\
Environmental impact [Pt] & 270.6 & 67.5 & 153.2 & 243.8 & 63.9 & 42.3 \\
Truncation level [\%] & 0.0 & 75.1 & 43.4 & 9.9 & 76.4 & 84.4 \\
Building B1 (wooden conventional) & & & & & & \\
Compromise solution (CS) & CS1 & CS2 & CS3 & CS4 & CS5 & CS6 \\
Environmental impact [Pt] & 230.7 & 87.9 & 133.7 & 211.8 & 83.2 & 67.2 \\
Truncation level [\%] & 0.0 & 61.9 & 42.1 & 8.3 & 64.0 & 70.9 \\
Building B2 (wooden passive) & & & & & & \\
Compromise solution (CS) & CS1 & CS2 & CS3 & CS4 & CS5 & CS6 \\
Environmental impact [Pt] & 257.1 & 65.0 & 154.5 & 238.0 & 61.7 & 42.7 \\
Truncation level [\%] & 0.0 & 74.7 & 39.9 & 7.4 & 76.0 & 83.4 \\
Average truncation level [\%] (as arithmetic mean) & 0.0 & 68.7 & 42.9 & 9.1 & 70.6 & 77.9 \\
\hline
\end{tabular}


Fig. 3 Eco-indicator results for masonry conventional building (A1) in six simplification variants (CS) [\%]. Source: SimaPro Analyst v.7.3.0/Impact $2002+$

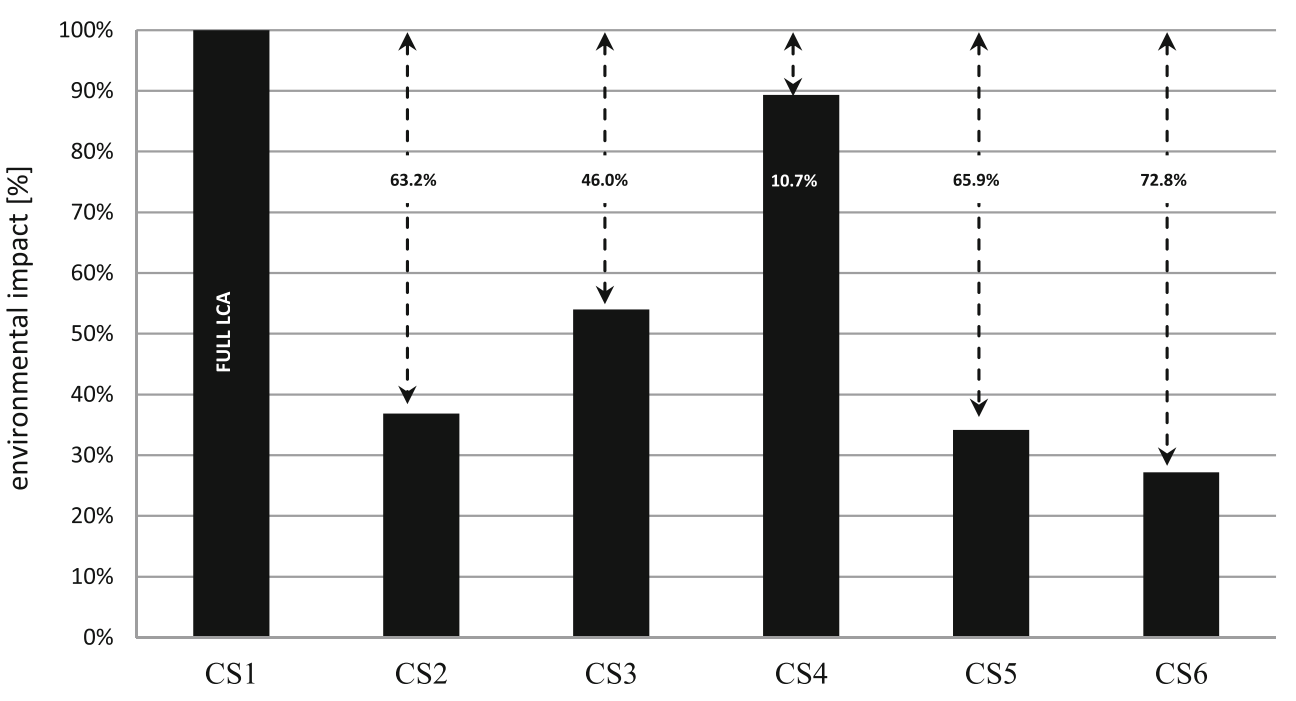

wastewater treatment) which resulted in 108 LCI points for A1 (reduction of $77.2 \%$ ), 98 for A2 (reduction of $78.4 \%$ ), 161 for B1 (reduction of $72.4 \%$ ) and 151 for B2 (reduction of $72.6 \%$ ). These inventory elements gave an eco indicator result of $90 \%$ (truncation levels of LCIA at $10 \%$ ), which seems to be a very good result from the point of view of the possibility to reduce the effort used to gather LCI data (Table 9).

\section{Conclusions}

The obtained results show that the simplifications included in the energy certification lead to a significant exclusion of the environmental impact $(77.9 \%$ on average) in relation to the impact calculated with full LCA.
On one hand, it could be argued that energy certification rightly focuses on the most sensitive environmental aspect, which is energy intensity during usage; however, it seems that the reasons for such a high level of truncation should be sought in two main areas:

- Simplification at LCI level, i.e. not including of all sources of energy usage in usage stages, and

- Simplification at LCIA level, i.e. including only of depletion of renewable energy carriers with exclusion of the entire spectrum of environmental issues included in the full environmental profile in LCA.

The analysis included at least two key impact categories: global warming and respiratory effect/inorganic compounds, which are critical for the life cycle of buildings (not limited to usage), and which are omitted
Fig. 4 Eco-indicator results for masonry passive building (A2) in six simplification variants (CS) [\%]. Source: SimaPro Analyst v.7.3.0/Impact $2002+$

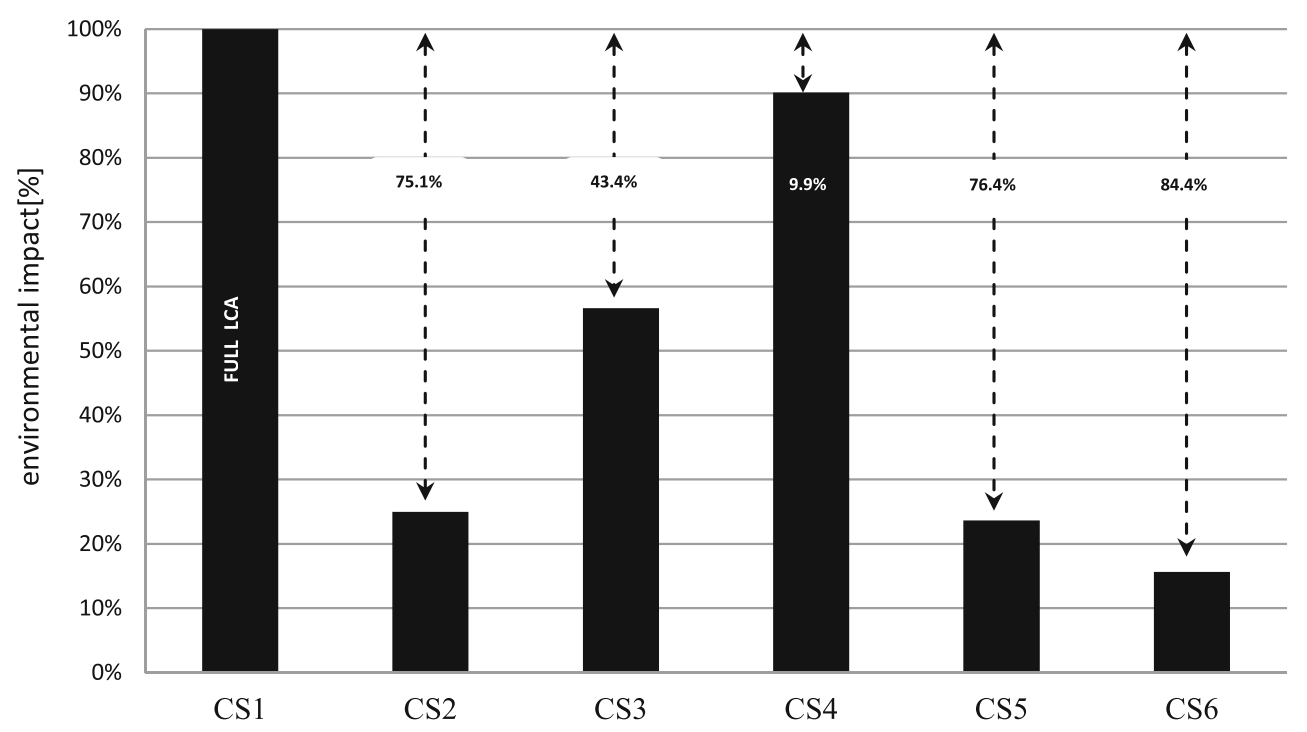


Fig. 5 Eco-indicator results for wooden conventional building (B1) in six simplification variants (CS) [\%]. Source: SimaPro Analyst v.7.3.0/Impact $2002+$

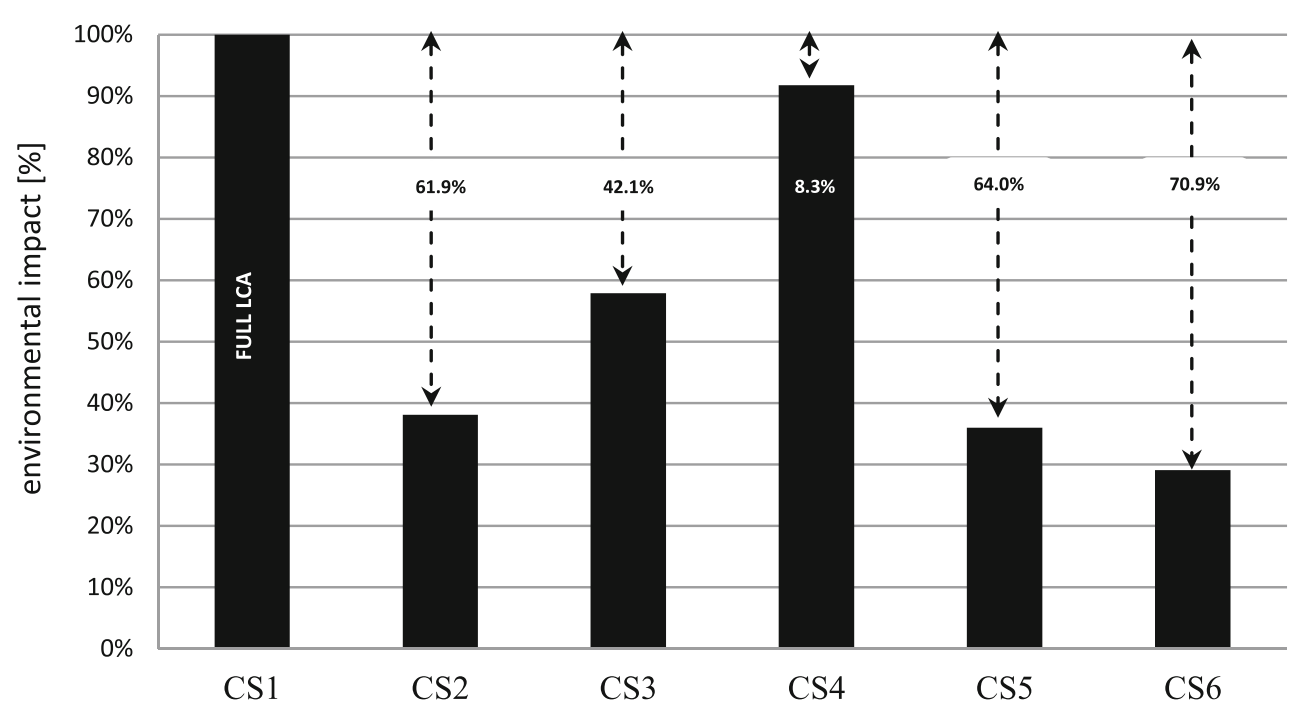

in energy certification. Assumptions based on the checking of the environmental burden of energy only for usage of non-renewable energy carriers is a simplification, whilst LCA (not limited to this project) show that, with regard to the cradle-to-grave perspective, energy production has many more environmental consequences.

In this context it is worth analysing the result obtained for the compromise solution 3 (CS3), which, from the inventory point of view, mirrors energy certification but includes all environmental interventions. In other words, in the case of CS3, the inventory table included only three elements typical for energy certificates, the usage of energy for: heating, ventilation and hot water, but the analysis was carried out with regard to all inputs and outputs occurring in the supply chain of these three energy-related inventory points and not, as in the case of energy certification, with regard to the use of energy only. The average truncation level of impact for CS3 was $42.85 \%$ and is significantly lower than the level obtained for CS6 (an average of $77.9 \%$ ).

\section{Recommendations}

In light of the obtained results, it seems that the rational compromise solution between the simplicity of the methodology and the environmental significance is compromise solution CS4, suggesting the inclusion of the production of building materials and additional elements associated with use of the building (energy use for home appliances, lighting as well as water use, wastewater treatment and land occupation). It is especially important in the context of newly built buildings,
Fig. 6 Eco-indicator results for wooden passive building (B2) in six simplification variants (CS) [\%]. Source: SimaPro Analyst v.7.3.0/Impact 2002+

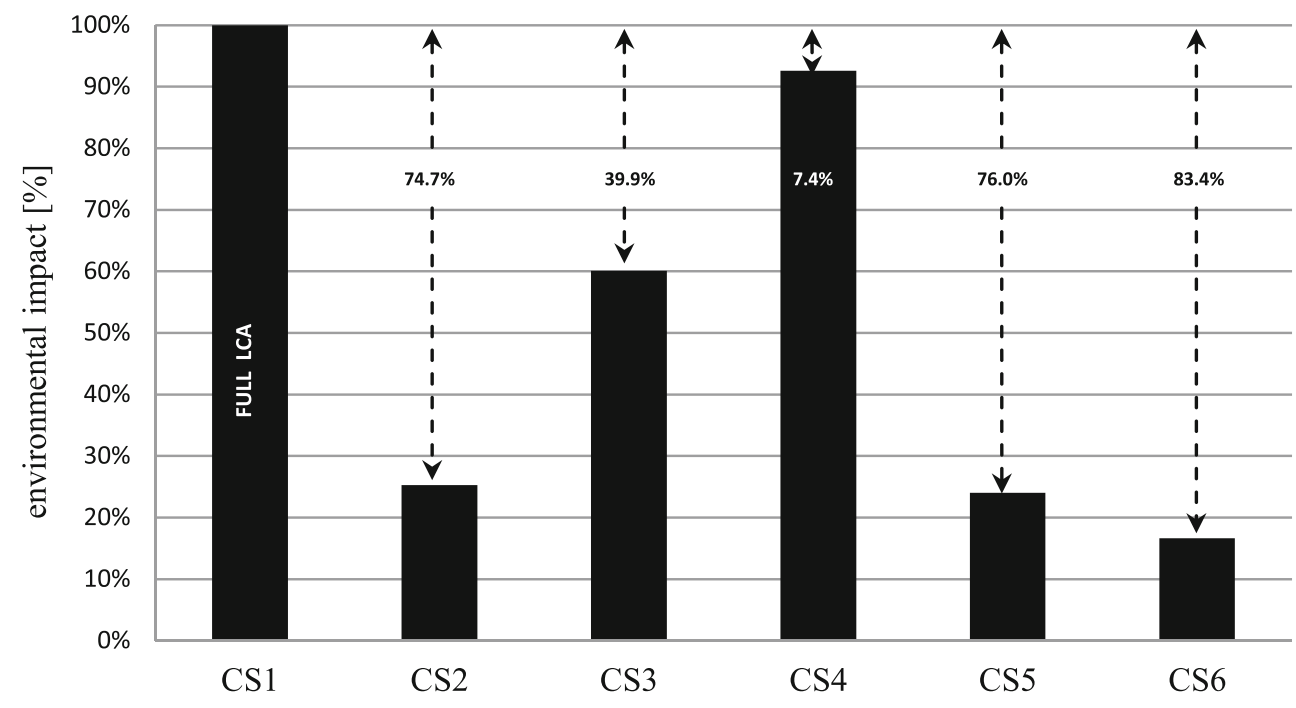


Fig. 7 Weighted impact categories indicator results for masonry conventional building (A1) in six simplification variants (CS) [\%]. Source: SimaPro Analyst v.7.3.0/Impact $2002+$

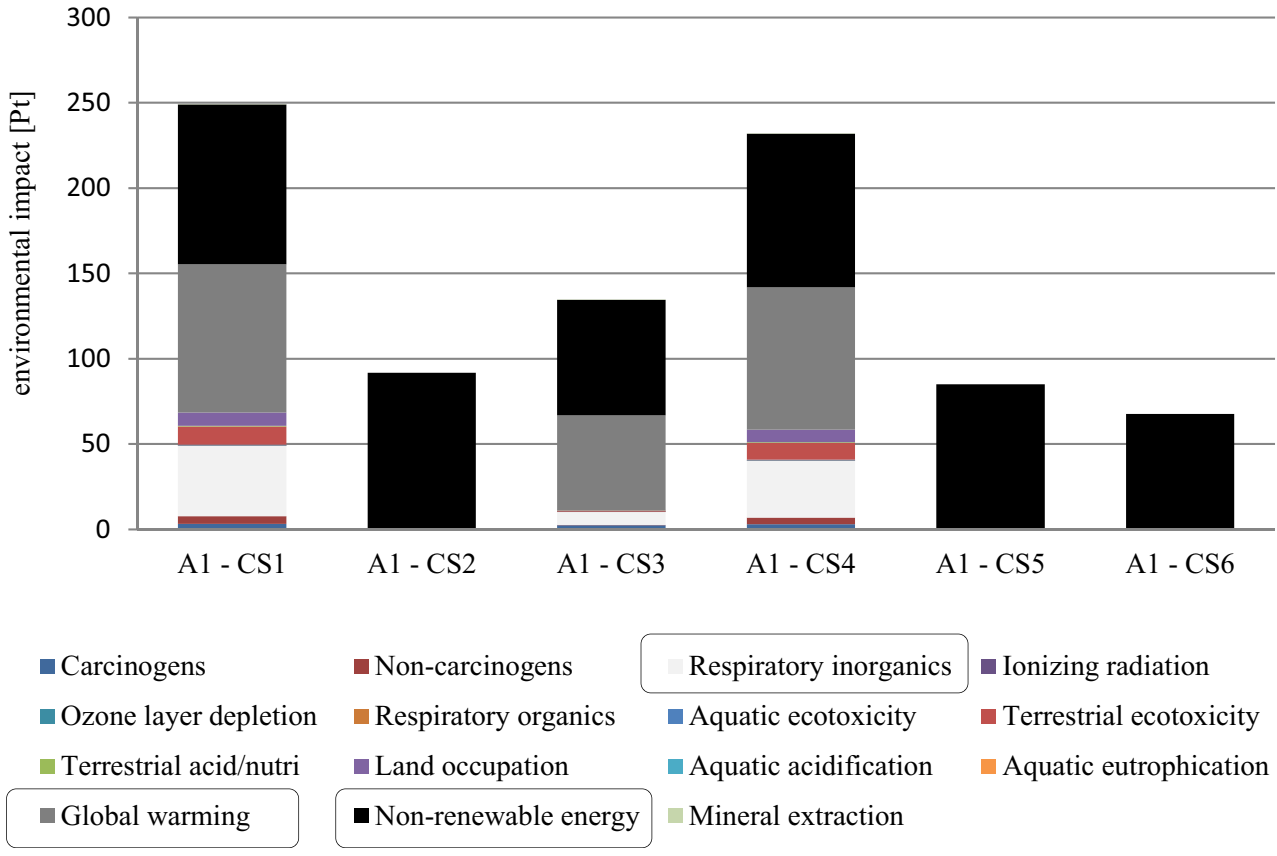

where the energy demand is very low so that the embodied energy of the materials can have a relatively significant share of the overall LCA results during a building's life cycle.

However, if looking for a solution that represents a rational minimum close to energy certification, then it seems that a good improvement would be to include to energy certification methodology the use of energy for home appliances, lighting

Table 9 Level of truncation [\%] of inventory data and LCIA results between CS1, CS3 and CS4

\begin{tabular}{|c|c|c|c|c|}
\hline \multicolumn{5}{|l|}{ Compromise solution CS1 } \\
\hline House & A1 & $\mathrm{A} 2$ & B1 & B2 \\
\hline $\begin{array}{l}\text { Number of inventory points } \\
\quad \text { (zero level of product system) }\end{array}$ & 474 & 453 & 584 & 552 \\
\hline Inventory truncation level [\%] & 0.0 & 0.0 & 0.0 & 0.0 \\
\hline Eco-indicator result $[\mathrm{Pt}]$ & 249.1 & 270.6 & 230.7 & 257.1 \\
\hline Impact truncation level [\%] & 0.0 & 0.0 & 0.0 & 0.0 \\
\hline \multicolumn{5}{|l|}{ Compromise solution CS3 } \\
\hline $\begin{array}{l}\text { Number of inventory points } \\
\text { (zero level of product system) }\end{array}$ & 3 & 3 & 3 & 3 \\
\hline Inventory truncation level [\%] & 99.4 & 99.3 & 99.5 & 99.5 \\
\hline Eco-indicator result $[\mathrm{Pt}]$ & 134.6 & 153.2 & 133.7 & 154.5 \\
\hline Impact truncation level [\%] & 46.0 & $43, .4$ & 42.1 & 39.9 \\
\hline \multicolumn{5}{|l|}{ Compromise solution CS4 } \\
\hline $\begin{array}{l}\text { Number of inventory points } \\
\text { (zero level of product system) }\end{array}$ & 108 & 98 & 161 & 151 \\
\hline Inventory truncation level [\%] & 77.2 & 78.4 & 72.4 & 72.6 \\
\hline Eco-indicator result $[\mathrm{Pt}]$ & 222.6 & 243.8 & 211.8 & 238.0 \\
\hline Impact truncation level [\%] & $10, .7$ & 9.9 & 8.3 & 7.4 \\
\hline
\end{tabular}

Source: SimaPro Analyst v.7.3.0/Impact 2002+ as well as the introduction of conversion factors based not only on depletion of energy sources but also including global warming and respiratory effects/inorganic compounds. According to the methodology for calculating the energy performance of the buildings and residential dwellings (O.J. 2008 No 201, item. 1,240), expenditure of non-renewable primary energy in energy certifications is defined by using conversion indicators for individual carriers of final energy (e.g. coal, lignite, heating oil, natural gas, liquid gas, heat from heating plants, etc.). These carriers are not treated there, using the LCA terminology, as elementary flows, but as inputs from the technosphere, which have their own technological history. Conversion indicators divide the final energy carriers depending on their "primary non-renewable energy demand", which results from their technological history. Theoretically, it would be possible to additionally calculate, for the same final energy carriers, and using the same system boundaries, the quantity of the emissions of greenhouse gases and inorganic compounds, which would allow conversion indicators to be supplemented with emission issues, not limited to the consumption of non-renewable resources. In such a situation, the indicators would not be connected only with the expenditure of primary non-renewable energy, but they would become more comprehensive eco-indicators that would also take into account other relevant issues in the image of environmental consequences of energy carrier production. Moreover, it seems that LCA, and characterisation parameters in particular, are refined to such a degree and scientifically proved that it would be possible to use the knowledge about the scope of LCA to establish such indicators for energy certification. 
Open Access This article is distributed under the terms of the Creative Commons Attribution License which permits any use, distribution, and reproduction in any medium, provided the original author(s) and the source are credited.

\section{References}

Blengini GA, Carlo TD (2010a) Energy-saving policies and low-energy residential buildings: an LCA case study to support decision makers. Int J Life Cycle Assess 15(7):652-665

Blengini GA, Carlo TD (2010b) The changing role of life cycle phases, subsystems and materials in the LCA of low energy buildings. Energy Build 42(6):869-880

Bribian IZ, Uson AA, Scarpellini S (2009) Life cycle assessment in buildings: state of the art and simplified LCA methodology as a complement for building certification. Build Environ 44:2510-2520

Casals XG (2006) Analysis of building energy regulation and certification in Europe: their role, limitations and differences. Energy Build 38:381-392

Dixit MK, Fernandez-Solis JL, Lavy S, Culp CH (2010) Identification of parameters for embodied energy measurement: a literature review. Energy Build 42(8):1238-1247

Dylewski R, Adamczyk J (2012) Economic and ecological indicators for thermal insulating building investments. Energy Build 54:88-95

EN 15804 (2012) Sustainability of construction works - environmental product declarations - core rules for the product category of construction products. CEN/TC 350

ISO 14040 (2006) Environmental management-life cycle assessment—p and framework.CEN; Brussels

ISO 14044 (2006) Environmental management-life cycle assessmentrequirements and guidelines. CEN; Brussels

ISO 21931-1 (2010) Sustainability in building construction-framework for methods of assessment of the environmental performance of construction works-part 1 Buildings. ISO TC/59

Kellenberger D, Althaus H-J (2009) Relevance of simplifications in LCA of building components. Build Environ 44:818-825

Kulczycka J, Pietrzyk-Sokulska E (eds) (2012) Evaluation of energy sector in Poland. MEERI, Cracow (in Polish). ISBN 978-8362922-14-7
Lewandowska A, Noskowiak A, Pajchrowski G, Strykowski W, Witczak A (2012) The environmental life cycle assessment of the model residential buildings constructed in masonry technology and wood technology - as an example of LCA application. Wood Technology Institute, Poznan, Poland. ISBN 978-83-932284-4-7 (in Polish), pp 264

Malmqvist T, Glaumann M, Scarpellini S, Zabalza I, Aranda A, Llera E, Díaz S (2011) Life cycle assessment in buildings: the ENSLIC simplified method and guidelines. Energy 36:1900-1907

O.J. (2002) No 75, item. 690 as amended (2002) - the regulation of the Minister of Infrastructure of 12 April 2002 on the technical conditions to be met by buildings and their location

O.J. (2008) No 201, item. 1,240 - the regulation of the Minister of Infrastructure of 6 November 2008 on the methodology for calculating the energy performance of the buildings and residential dwellings or part of a building comprising a self-contained entity and the preparation and presentation of energy performance certificates

Optis M, Wild P (2010) Inadequate documentation in published life cycle energy reports on buildings. Int J Life Cycle Assess 15:644-651

Ortiz O, Castells F, Sonnemann G (2009) Sustainability in the construction industry: a review of recent developments based on LCA. Constr Build Mater 23:28-39

Pajchrowski G, Noskowiak A, Lewandowska A, Strykowski W (2014a) Wood as a building material in the light of environmental assessment of full life cycle of four buildings. Constr Build Mater 52:428-436

Pajchrowski G, Noskowiak A, Lewandowska A, Strykowski W (2014b) Materials composition or energy characteristic - what is more important in environmental life cycle of buildings? Build Environ 72:15-27

Passer A, Kreiner H, Maydl P (2012) Assessment of the environmental performance of buildings: a critical evaluation of the influence of technical building equipment on residential buildings. Int J Life Cycle Assess 17(9):1116-1130

Rossi B, Marique A-F, Glaumann M, Reiter S (2012) Life-cycle assessment of residential buildings in three different European locations, basic tool. Build Environ 51:395-401

The Act of 7 July 1994 Construction Law; as amended 2006, 2007, 2009

The Directive 2002/91/EU of the European Parliament and of the Council of 16 December 2002 on the energy performance of buildings, O.J. L 001, 04/01/2003 P. 0065 - 0071

The Directive 2010/31/EU of the European Parliament and of the Council of 19 May 2010 on the energy performance of buildings, O.J. L 153, $18 / 06 / 2010$ P. $0013-0035$ 